\title{
O TEMPO DA JUSTIÇA NO CÓDIGO DE PROCESSO CIVIL
} THE TIME OF JUSTICE IN THE CIVIL PROCEDURE CODE

\author{
Benedito Cerezzo Pereira Filho* \\ Daniela Marques de Moraes
}

\section{RESUMO}

O tempo da justiça deve ser considerado um direito fundamental e toda a interpretação legislativa ou jurisprudencial tem de levar em consideração o ônus que ele poderá acarretar às partes. Não por outra razão, o direito à prestação jurisdicional em tempo razoável foi erigido à garantia fundamental (art. $5^{\circ}$, LXXVIII, CF). O Código de Processo Civil, por sua vez, alberga essa garantia e igualmente se compromete a realizar um processo justo, em conformidade com o direito fundamental insculpido na Constituição Federal. A partir destas considerações, utilizando-se do método de análise bibliográfica e jurisprudencial, buscou-se examinar o impacto do tempo nas demandas cíveis e a sua '(in)suportabilidade' presentes nas decisões judiciais, concluindose pela necessidade de equilíbrio do ônus do tempo entre as partes, com a crítica pela escolha legislativa de se manter o efeito suspensivo automático no recurso de apelação.

PALAVRAS-CHAVE: Justiça. Tempo. Duração. Razoável. Suportável. Processo.

\begin{abstract}
The time required to delivery justice must be considered a fundamental right that should be taken in consideration by legislative $e$ judicial interpretation, specially considering it as a burden to adversary parties. That is way it (reasonable judgment time) was elected as a constitutional right in article $5^{\circ}$, LXXVIII, CF. The code of civil procedures also hosts such right abiding influence of the Constitution. From those considerations, by the bibliographical and jurisprudential methods, this paper aims to analyze how that time affects the parties and the judicial decisions. Its conclusion was that the parties have to hold those affects in a balanced way, what does not tend to occur with the legislative option to maintain appeal suspensive effect.
\end{abstract}

KEYWORDS: Justice. Time. Duration. Reasonable. Tolerable. Process.

\section{INTRODUÇÃO}

O tempo do processo há muito representa uma preocupação. A conscientização a respeito dos possíveis prejuízos decorrentes da duração dos processos, na maioria das vezes de sua longa duração, trouxe como resultado a introdução da garantia fundamental da razoável duração do processo, pela Emenda Constitucional $n^{\circ} 45 / 2004$, insculpida no art. 5º LXXVIII da Constituição Federal.

* Professor Adjunto na Graduação e no Programa de Pós-Graduação (Mestrado e Doutorado) da Faculdade de Direito da Universidade de Brasília (FD/UnB). Doutor em Direito pela Universidade Federal do Paraná - UFPR.E-mail: benedito.cerezzo@unb.br.

* Professora Adjunta na Graduação e no Programa de Pós-Graduação (Mestrado e Doutorado) da Faculdade de Direito da Universidade de Brasília (FD/UnB). oordenadora de Graduação da Faculdade de Direito da Universidade de Brasília (FD/UnB). Doutora em Direito pela Universidade de Brasília -UnB.E-mail: danielamoraes@unb.br. 
Esta garantia constitucional, em verdade, tem sua referibilidade a um tempo em abstrato, sem possibilidade de estabelecer, por exemplo, o modo de se auferir o que seria o tempo razoável de um processo, comprometendo a própria expectativa de efetividade da justiça.

A pesquisa, diante deste contexto, tem como objetivos examinar o impacto do tempo no desenvolvimento das ações processuais, o alcance da suportabilidade, pelas partes, deste tempo, bem como as possíveis interferências legislativas e judiciais na implementação de técnicas processuais e no exercício da atividade jurisdicional capazes de equilibrar, entre os jurisdicionados, o ônus do tempo.

A metodologia do trabalho incide na abordagem do objeto por meio de estudo crítico-dialético, com procedimento metodológico consistente no levantamento bibliográfico e jurisprudencial, mediante a utilização de livros, artigos científicos, casos práticos, decisões judiciais e demais documentos concernentes ao tema, visando o alcance do problema proposto: o impacto do tempo da justiça cível na prestação da tutela jurisdicional e sua consequência para as partes.

O Código de Processo Civil, Lei $n^{0} 13.105 / 2015$, cuja vigência iniciou-se em 18 de março de 2016, como objetivo primordial, elegeu a diminuição do tempo no processo, prometendo às partes uma solução integral do mérito, incluindo a atividade satisfativa (vide seu art. $4^{\circ}$ ).

Importante destacar que não se trata de uma mera declaração. É uma norma vocacionada à garantia de um direito fundamental: a duração razoável do processo. Direito fundamental sem garantia, é o mesmo que não ter direito. Do que adiantaria o direito fundamental de ir e vir, sem a garantia do habeas corpus; do direito líquido e certo, sem a garantia do mandado de segurança; o direito ao assecuramento de conhecimento de informações relativas à pessoa, sem o habeas data etc.

Por isso que "O Estado, antes de tudo, tem o dever de proteger os direitos fundamentais mediante normas de direito." ${ }^{1}$ No entanto, essa mesma norma de garantia (art. $4^{\circ}$ do CPC) tem potencial fundamentalidade na exata medida em que foi inserida no Capítulo I, destinado às normas fundamentais do processo civil.

As normas fundamentais dispostas no início do Código de Processo Civil, desde logo, orientam a todos o seu propósito de compromisso com os direitos fundamentais, tanto que reproduzem aquelas previstas na Constituição. ${ }^{2}$

Essa opção legislativa de 'abrir' o Código com os direitos fundamentais é uma tendência observada em outros modelos jurídicos, como, por exemplo,

MARINONI, 2017, p. 23;

"As normas fundamentais do processo civil estão obviamente na Constituição e podem ser integralmente reconduzidas ao direito fundamental ao processo justo (art. $5^{\circ}$, LIV, CF)." MARINONI; ARENHART; MITIDIERO, 2016, p. 142; 
"o Code francês principia enunciado príncipes directuers du procès e as Civil Procedure Rules inglesas começam pela exposição do seu overriding objecitve." ${ }^{3}$

Essa simbiose fortalece a ideia de que toda aplicação das normas previstas no Código de Processo Civil deve, obrigatoriamente, seguir essa orientação inicial de comprometimento integral com os direitos fundamentais.

$\mathrm{O}$ direito fundamental à tutela jurisdicional efetiva exige, no mesmo plano, normas (arts. $4^{\circ}, 6^{\circ}, 7^{\circ}$ e $8^{\circ}$ do $\mathrm{CPC}$ ) e técnicas processuais (tutelas de urgência, meios executivos adequados e execução imediata das decisões) que garantam às partes a razoável duração do processo.

É a partir, portanto, dessa vertente, que se propõe analisar a questão do tempo da justiça no Código de Processo Civil. Para tanto, esmerou-se em exprimir a compreensão do direito de ação como integrante do rol dos direitos fundamentais (item 2). No tópico 3, demonstrou-se o que se entende por duração 'suportável' do processo, ao passo que no seguinte desenvolveu-se a ideia de como se deve verificar o tempo do e no processo (subitem 3.1). No item 4, por sua vez, correlacionou-se o tempo do processo com a necessidade de observância dos direitos fundamentais, enquanto que, no tópico 5 , se realizou o cotejo entre o sistema recursal e o tempo do processo, com a extensão da análise para a incompatibilidade entre os princípios da duração razoável do processo e do duplo grau obrigatório (subitem 5.1), alcançando-se como considerações finais a necessidade de se dividir o ônus do tempo entre as partes, evitando-se tutelas preventivas que perdurem demasiadamente, sob a luz da crítica que recai pela opção legislativa em se manter o efeito suspensivo do recurso de apelação.

\section{A AÇÃO COMO DIREITO FUNDAMENTAL}

A compreensão do direito de ação como integrante do rol dos direitos fundamentais, bem como, sua exata pertinência para o processo (ação de direito processual) e para o direito material (ação de direito material), é de extrema relevância para se entender a questão do tempo no processo e as consequências que acarreta para as partes.

Não deveria ser novidade o fato de que o cidadão não vai ao judiciário por escolha, predileção. Ao contrário, por estar proibido de fazer justiça pelas próprias mãos, ele é obrigado a se valer do sistema de justiça que o poder público lhe disponibiliza. A 'opção' pelas vias legais, é, de verdade, uma imposição àquele que necessita de justiça para uma determinada situação.

Não por outra razão, o artigo 345 do Código Penal censura àquele que ousar a fazer justiça de mãos próprias: "fazer justiça pelas próprias mãos, para satisfazer pretensão, embora legítima, salvo quando a lei o permite: Pena - de-

3 MARINONI; ARENHART; MITIDIERO, 2016, p. 142; 
tenção, de quinze dias a um mês, ou multa, além da pena correspondente à violência." 4

A equação é simples: diante de uma ameaça ou lesão a direito, o ofendido, após não obter sucesso com o ofensor para que cesse a ameaça ou repare o dano (ação de direito material), só terá como alternativa a ida ao poder judiciário (ação de direito processual). ${ }^{5}$

Por isso, defende-se ${ }^{6}$ que jurisdição, antes de ser poder, é, em verdade, um dever. O poder, assim, está a serviço do dever, ou seja, o seu uso é devido para, justamente, permitir que o juiz se desincumba do seu ônus.

O Estado que pró́be o particular de fazer justiça pelas próprias mãos, prometendo fazê-la em seu lugar, desde que devidamente acionado pela via processual, é um devedor comprometido com a solução da lide de forma adequada, tempestiva e efetiva, sob pena de permitir que a ação de direito material seja realizada de mãos próprias.

O primeiro diálogo do autor é com o juiz: _ Estou cobrando a promessa a mim feita de que minha ação de direito material, a qual fui obstado a agir privadamente, será, com esse meu agir processual (ação de direito processual), realizada por vossa excelência. A ação, então, é ajuizada contra o juiz (Estado/ juiz) e em face do réu.

"Deixe-se claro, em primeiro lugar, que a ação é a contrapartida natural da proibição da tutela privada, ou seja, é o instrumento de que o particular passou a fazer uso diante da eliminação da 'justiça de mão própria'". ${ }^{7}$ Diante desse cenário, é forçoso concluir que o direito de ação se insere no rol dos direitos fundamentais.

O raciocínio parece óbvio. Se a tutela privada é proibida pelo Estado, a tutela pública a ser por ele prestada, tem de ser adequada, tempestiva e efetiva, abarcando amplo acesso.

Cônscia desse dever, a Constituição Federal apregoa no art. $5^{\circ}$, XXXV que "A lei não excluirá da apreciação do Poder Judiciário lesão ou ameaça a direito". Esse dispositivo, aliás, é reproduzido no Código de Processo Civil, precisamente, no art. $3^{\circ}$.

Trata-se, pois, do assentimento de que a ação como direito fundamental requer uma tutela jurisdicional adequada, tempestiva e efetiva, fruto, também, do direito à universalidade da jurisdição.

4 O uso da força somente é lícito, em raras situações e, somente, quando autorizado pela legislação, como por exemplo, no direito de retenção por benfeitorias necessárias ou úteis (Código Civil, art. 578).

5 As categorias de ação de direito material e ação de direito processual foram muito bem trabalhadas por Ovídio Araújo Baptista da Silva. O estudo dessas "ações" é de extrema importância para a compreensão do direito.

6 A esse respeito, ver: PEREIRA FILHO, 2006, pp. 19-33;

7 MARINONI; ARENHART; MITIDIERO, 2016, p. 191; 
Nesse ponto, ensinam Luiz Guilherme Marinoni, Sérgio Cruz Arenhart e Daniel Mitidiero:

As partes não têm apenas direito à jurisdição - diante da ordem jurídica brasileira, têm direito à jurisdição com cobertura universal a ser prestada por um juiz natural (art. 5, XXXV, XXXVII e LIII da CF/1988). Além de estarem previstos como elementos do direito fundamental ao processo justo (art. $5^{\circ}$, LIV da CF/1988), a universalidade do direito à jurisdição e o direito ao juiz natural também foram alvos de atenção do novo Código de Processo Civil $\left(\operatorname{art.} 3^{\circ}\right) .^{8}$

Importante compreender, também, que o direito fundamental de ação, está acompanhado de outros, de igual standard, justamente, para que o Estado seja capaz de desempenhar seu dever de prestar, devidamente, a tutela jurisdicional a quem dela necessitar.

Como bem afirmam os processualistas acima citados:

A realização do direito de acesso à justiça é indispensável à própria configuração de Estado, uma vez que não há como pensar em proibição da tutela privada e, assim, em Estado, sem se viabilizar a todos a possibilidade de efetivo acesso ao Poder Judiciário. Por outro lado, para se garantir a participação dos cidadãos na sociedade, e dessa forma a igualdade, é imprescindível que o exercício da ação não seja obstaculizado, até porque ter direitos e não poder tutelá-los certamente é o mesmo do que não os ter. ${ }^{9}$

De acordo com essa ordem de ideia, o acesso à justiça não significa a mera possibilidade de ida ao judiciário e, muito menos, de se ter uma sentença que reconheça o direito da parte.

Jurisdição não se encerra com declaração, mas, ao contrário, com efetivação do direito reconhecido em juízo. A universalização do acesso à justiça é corolário de uma tutela jurisdicional que seja adequada, tempestiva e efetiva.

A parte tem, então, de receber a tutela do seu direito invocado em juízo e não a obrigação subsidiária ou o equivalente em dinheiro (tutela adequada); essa prestação jurisdicional, por sua vez, tem de ser proferida dentro de um tempo razoável (tutela tempestiva) e; o direito reconhecido na decisão tem de ser satisfeito, entregue à parte (tutela efetiva).

\section{A DURAÇÃO 'SUPORTÁVEL' DO PROCESSO (ART. 5o, LXXVIII, CF)}

Fosse dado conceituar processo civil de forma sucinta e livre, mas, suficiente para retratar o que ele representa para as partes, poder-se-ia dizer que processo é prazo e prova. A parte tem o ônus da prova das suas alegações e os atos processuais, por sua vez, são praticados nos prazos devidamente determinados.

8 MARINONI; ARENHART; MITIDIERO, 2016, p. 183;

9 MARINONI; ARENHART; MITIDIERO, 2016, p. 219; 
No caso, interessa o prazo em que as partes são obrigadas a suportar a espera da tutela do direito invocado e as consequências desse tempo na vida dos jurisdicionados, levando-se em consideração o direito fundamental a um processo de razoável duração.

O tempo é o único bem irrecuperável. Não é passível de ser adquirido. Uma vez 'perdido', os efeitos são irreversíveis. No processo, contudo, ele pode, ao mesmo tempo, ser prejudicial a uma parte e extremamente benéfico à outra.

É mais do que evidente, no entanto, que a prestação da tutela jurisdicional demanda tempo para ser processada. O tempo é um ônus no e do processo contra o qual o Estado/juiz precisa lutar para amenizar, ao máximo, seus deletérios efeitos.

Não se nega que o tempo sempre foi um desafio para o processualista. Francesco Carnelutti há muito prescrevia que "O tempo é um inimigo implacável do processo, contra o qual todos - o juiz, seus auxiliares, as partes e seus procuradores - devem lutar de modo obstinado."10

Não por outra razão, essa questão mereceu atenção do Constituinte e foi erigida a status de direito fundamental pela Emenda Constitucional n ${ }^{\circ} 45 / 2004$ que instituiu o princípio da razoável duração do processo dentro das garantias fundamentais asseguradas a cada cidadão, previsto no inciso LXXVIII, do art. $5^{\circ}$ : "a todos, no âmbito judicial e administrativo, são assegurados a razoável duração do processo e os meios que garantam a celeridade de sua tramitação.”

Correligionário da tempestividade, a efetividade é outro objetivo que não pode ser esquecido. Processo rápido, ${ }^{11}$ mas não efetivo, se equivale à morosidade agravada pela desilusão do 'ganhar, mas não levar'. Durabilidade e efetividade são objetivos que se equivalem e, assim, devem ser alcançados simultaneamente.

O Código de Processo Civil de 2015 foi pensado, basicamente, sob essa perspectiva. Toda inovação, como simplicidade procedimental, resolução de demandas repetitivas, procedimento único, racionalização recursal etc. foram medidas tomadas visando, em última análise, a durabilidade do processo. ${ }^{12}$

Quanto ao tempo, para impedir um injusto dano processual, é preciso racionalizar o seu uso no processo para evitar que beneficie uma parte em detrimento da outra. A consequência que a má distribuição do uso do tempo traz para a parte no processo é aferível de forma objetiva, ou seja, ele em si é suficiente para causar dano. Todavia, a depender da situação da parte, das suas qualidades subjetivas, ele será ainda mais danoso. O que se pretende enfatizar

10 CARNELUTTI, 1958, p. 354.

11 Duração razoável do processo não significa, em absoluto, processo célere, rápido, sem que as partes possam desfrutar de um contraditório participativo. O que se deve buscar é a eliminação de atos processuais desnecessários e omissão, tanto das partes como do juízo.

12 À época da elaboração do Projeto de Lei 166/2010, com trâmite no Senado Federal, ficou conhecidíssima uma expressão utilizada pela Relatora, Teresa Arruda Alvim, que, na oportunidade, discorrendo sobre a questão recursal, no que entendia ser um excesso, falou à imprensa: "o juiz espirra e o advogado recorre". 
é o fato de que umas pessoas são mais suscetíveis à suportabilidade do ônus do tempo no processo do que outras.

A compreensão do que venha a ser prazo razoável não é tarefa das mais fáceis. Para nós, e socorrendo-nos da hermenêutica, pois a Constituição Federal utiliza duração razoável, o próprio termo merece ser adequado à realidade forense.

Seria mais propício utilizar a expressão suportável. É que razoável dá o sentido (o critério) de algo distante das partes. Transforma-o em etéreo, metafísico, abstrato. Leva em consideração, em sua definição, até as dificuldades próprias da jurisdição, que, aliás, não podem ser transferidas para as partes.

Por outro lado, este critério da razoabilidade acaba igualando os desiguais, pois, até a parte mais forte na relação jurídica processual, seja qual for o interesse, por vezes até mesquinho, terá legitimidade para levantar esta bandeira. Enquanto que o 'suportável', relaciona-se diretamente com as partes envolvidas, com sua real necessidade $d a$ e na prestação jurisdicional, por se constituir em algo direto, concreto, objetivo, topicamente considerado.

Não é novidade que o processo proporciona, em regra, dor, muita dor, que tem, assim, tempo de suportabilidade. Já a razoabilidade não se relaciona com a dor. O insuportável leva à derrota mesmo que não se perca; leva à morte, à guerra, ao suicídio, à luta de mão própria.

O insuportável, decorrente da demora, impõe uma análise objetiva, direta, concreta, do que se passa na vida do litigante: um dia de demora pode ser insuportável, mas, ao contrário, um dia de demora jamais será irrazoável. O direito do mais forte na relação jurídica processual, nunca será insuportável. Talvez por isso, optou-se pelo razoável em vez do suportável.

Seja como for, o importante é ter consciência destas questões ao decidir e satisfazer. Mesmo porque, se o método do direito é tópico, destinado a resolver problema no aqui e no agora, tendo pela frente um caso único a exigir resposta única, particularizada, fará eclodir uma 'suportabilidade' que também se afigura como única.

\subsection{COMO AUFERIR O TEMPO DO E NO PROCESSO?}

Como já dito acima, o tempo, apesar de ser um ônus, é inerente ao processo. Não tem como pensar em eliminá-lo. Por essa decisiva razão, ele não pode ser pensado apenas pela ótica da durabilidade do processo, entendido, como começo e fim dentro de um prazo razoável. É imprescindível para o processo o seu tempo de maturação e, pois, duração.

O que se intenta demonstrar é que o processo em si, compreendido desde a petição inicial até a decisão final, por circunstâncias várias, requer um tempo de durabilidade que, em regra, não consegue atender o comando constitucional da duração razoável do processo. 
O que precisa ser compreendido, então, é que a parte, seja ela autora ou ré, não pode se submeter à decisão que se prolongue no tempo causando-lhe, em si e por si, dano pela 'simples' duração. À luz do princípio da duração razoável do processo, o juiz não pode impingir à parte uma medida judicial irrazoável, ou seja, que se eternize no tempo.

Um exemplo da prática jurídica, usual no dia-a-dia forense, pode auxiliar. O deferimento de uma medida cautelar de indisponibilidade de bens proferida nas ações que investiga atos de improbidade administrativa que perdure muito além do necessário, fere o direito da parte ré a, também, ser titular da garantia de efetividade dos meios processuais aptos a não lhe submeter a um processo injusto pelo decurso do tempo.

A doutrina de Luiz Guilherme Marinoni ensina que:

O direito do réu, mais do que exigir prestações positivas do Estado, tem a configuração de direito de defesa, constituindo uma garantia do cidadão contra o Estado, precisamente uma garantia de que não será submetido ao poder estatal - jurisdicional ou administrativo - por mais tempo que o necessário. [sem grifo no original ${ }^{13}$

Por isso, o alerta acima de que o tempo do processo, antes mesmo de ser razoável, tem de ser suportável. ${ }^{14}$

Bem vistas as coisas, não é o processo, compreendido o lapso de tempo que vai da petição inicial ao seu término - decisão transitada em julgado e efetivada -, que deve ter uma duração razoável.

O razoável, para nós, suportável, está adstrito às medidas que são tomadas no curso do processo e que acarretam 'dano'15 às partes. Ou seja, o que é insuportável não é a duração do processo em si, mas, a falta de racionalidade do uso do tempo para a prática - deferimento ou indeferimento - de medidas necessárias à tutela dos direitos. Assim, toda medida judicial, principalmente, a que impõe restrição a direito fundamental, deve obedecer a um tempo que seja, antes de tudo, suportável para a parte.

No caso da medida de indisponibilidade de bens e bloqueios em contas correntes, usualmente deferidas em ação por ato de improbidade administrativa, é comum a parte ré conviver com essa restrição durante todo o trâmite processual, cujo tempo de duração, em média, ultrapassa 10 (dez) anos.

Nem mesmo o Superior Tribunal de Justiça, intitulado de Tribunal da Cidadania, demonstra compreender que medida cautelar não pode se eternizar no tempo. Deve ela guardar necessidade com o direito material carente de urgência, sendo, então, temporária e não provisória.

13 MARINONI, 2009, p. 84.

14 PEREIRA FILHO, 2015, p. 52.

15 Dano no sentido lato, ou seja, prejuízo de toda sorte, que não só o estritamente quantificável economicamente de plano, mas, por exemplo, a perda de uma chance, a angústia pela espera insuportável etc. 
Essa provisoriedade não pode ser entendida como algo que vá perdurar até ser substituída pela decisão final de mérito que, como é sabido, tendo em vista todo o desenrolar de um processo complexo, cujo tempo é extremamente excessivo, onerará unicamente a parte sobre quem a medida for imposta.

Algumas posições no Superior Tribunal de Justiça, apesar de coerente com o sistema de justiça pátrio, são isoladas, como o voto vencido do Min. Napoleão Nunes Maia Filho:

Portanto, sem pretender afastar o precedente firmado por esta Corte Superior pelo rito do art. 543-C, entende-se que a hipótese vertente não comporta a indisponibilidade dos bens dos Réus, por se tratar de Ação Civil Pública ajuizada em 2007, que ainda não foi sentenciada, conforme se dessume do andamento processual da página eletrônica do TJ/MT Processo 236/2007, Código 29529, fls. 41). Está em fase de plena instrução, sendo certo que eventual bloqueio de bens dos Réus por todos os anos, desde 2007, se mostraria inarredavelmente oneroso. [...] Nesse sentido, reverenciando os princípios da razoabilidade e da proporcionalidade - já proclamados pelas Instâncias de origem -, não se justifica manter indisponíveis os bens dos Réus em constrição meramente ancilar de eventual condenação no feito, que, aliás, não se tem previsão alguma de desfecho, nem em termos temporais, nem mesmo quanto ao tema de fundo, isto é, se haverá decreto condenatório por ato de improbidade administrativa. [sem grifo no original $]^{16}$

A posição acima transcrita, revela que "A demora processual foi tratada, por parcela da doutrina, como algo meramente acidental ao processo e por isso destituída de qualquer importância para um 'discurso científico'." ${ }^{17}$

Esse equívoco de interpretação, oriundo, inclusive do STJ, não é praticado somente nas lides que envolvam discussões sobre atos de improbidade administrativa. O descompromisso com o tempo no processo é prática corriqueira nas lides cíveis no direito brasileiro e se irradia por toda jurisdição.

A ação rescisória número 4590/PR, ${ }^{18}$ em curso no Superior Tribunal de Justiça, é um exemplo claro do que se está discutindo. Nela, a Relatora deferiu pedido antecipatório para suspender o cumprimento de sentença em face do Banco réu, no dia 17 de dezembro de 2010, e não se decidiu mais nada no processo, apesar de a parte autora ter interposto agravo regimental, atual agravo interno.

É o típico caso em que a medida de urgência submete apenas uma parte à duração insuportável do processo, ao passo que beneficia a outra na exata medida em que permite a ela usufruir do bem da vida, no caso, valores indenizatórios, ao longo do tempo.

16 BRASIL. Superior Tribunal de Justiça. Recurso Especial n 1.189.008 - MT (2010/00652698). Rel. Min. Napoleão Nunes Maia Filho. Julgado em 17/05/2016. Publicado no DJE em $17 / 06 / 2016$.

17 MARINONI; ARENHART; MITIDIERO, 2016, p. 221.

18 BRASIL. Superior Tribunal de Justiça. Ação Rescisória no 4590/PR. Rel. Min. Maria Izabel Gallotti. Segunda Seção do Superior Tribunal de Justiça. Processo em andamento. 
Afirmam os processualistas Luiz Guilherme Marinoni, Sérgio Cruz Arenhart e Daniel Mitidiero:

Quando o autor pede uma soma em dinheiro ou uma coisa móvel ou um imóvel, quanto mais o processo dura mais o autor tem de esperar para obter o bem reivindicado e, em contrapartida, mais tempo o réu tem para usufruir o bem que está em sua esfera patrimonial. ${ }^{19}$

É mais do que evidente, no caso, de que se a instituição financeira for compelida a pagar, nada perderá, pois: primeiro, apenas entregará à outra parte um bem que não lhe pertencia e; segundo, ganhou muito com o tempo do processo, até agora, 08 (oito) anos só no STJ, ou seja, durante todo o trâmite processual, o Banco ficou na posse, usando, usufruindo e dispondo do bem da vida disputado nos autos.

A título informativo, a ação de prestação de contas que redundou na condenação do Banco ao pagamento de R \$ 3.311.331,88 (três milhões, trezentos e onze mil, trezentos e trinta e um Reais e oitenta e oito centavos) ao autor, alvo da ação rescisória acima aludida, tem os seguintes marcos temporais: 1) foi ajuizada em novembro de 1999; 2) sentença proferida em dezembro de 2001; 3) acórdão do TJ/PR proferido em setembro de 2002; 4) recurso especial interposto em janeiro de 2007 e julgado, monocraticamente, em junho de 2010 e; 5) ação rescisória ajuizada em novembro de 2010, com liminar decretando a suspensão do cumprimento de sentença em dezembro de 2010.

Assim, o Banco Réu está aplicando o dinheiro do autor há mais de 18 (dezoito) anos. Para ele, nessas condições, litigar é um ótimo negócio. O tempo lhe é extremamente útil, sendo "Fácil concluir que o autor com razão é prejudicado pelo tempo da justiça na mesma medida em que o réu sem razão é por ela beneficiado. Vistas as coisas através desse ângulo, fica muito claro o valor que o tempo possui diante desses conflitos.”20

O obstáculo à prestação da tutela jurisdicional de forma adequada, tempestiva e efetiva, assim, não está na duração do processo em si, mas, na irracionalidade de se manter medida judicial cuja permanência torna a situação da parte adversa, insuportável, ao passo que beneficia de forma injusta a outra.

Casos como esses, usuais na justiça cível brasileira, joga na vala comum os direitos e as garantias fundamentais dos jurisdicionados, negando o sentido e a função da jurisdição constitucional.

19 MARINONI; ARENHART; MITIDIERO, 2016, p. 221.

20 MARINONI; ARENHART; MITIDIERO, 2016, p. 221. 


\section{O COMBATE AO TEMPO DO PROCESSO TEM DE GUARDAR COERÊNCIA LÓGICA COM OS DIREITOS FUNDAMENTAIS}

A técnica antecipatória não pode sacrificar direitos inerentes à garantia de um procedimento que deve ser realizado em contraditório efetivo. Não se pode perder de vista que, se o direito de ação é fundamental, também o é o direito de defesa. Assim, há impossibilidade de se decretar tutela da evidência sem defesa, direta ou indireta, apresentada pelo réu. Inconstitucionalidade do art. $7^{\circ}$ da Lei 8.429/92 e do art. 311, parágrafo único do Código de Processo Civil.

Tem-se assistido, nos últimos anos no cenário jurídico brasileiro, uma tendência a sacrifícios de direitos fundamentais em nome do combate à corrupção e demais anomalias. Para facilitar o trabalho da acusação, a jurisprudência do Superior Tribunal de Justiça, nas ações de improbidade administrativa, vem empregando à tutela da evidência uma interpretação à margem da Constituição Federal.

O alerta da doutrina de que o comprometimento ideológico existente em toda e qualquer decisão não pode permitir o retrocesso, encontra limites na própria legislação ordinária e, principalmente, na Constituição Federal. ${ }^{21}$

Interpretação carente de racionalidade sólida está vocacionada à mácula da inconstitucionalidade: "Nem o decantado interesse público é suficiente para fundamentar interpretações lançadas à contramão da história de luta por conquistas de direitos fundamentais." 22

Dizer que o artigo $7^{\circ}$ da Lei $8.429 / 92^{23}$ reflete uma tutela da evidência, além do equívoco interpretativo, contribui para a construção de um dispositivo inconstitucional. O referido dispositivo não autoriza essa interpretação, em nenhuma das suas espécies, e a conclusão a que se chegou e, portanto, a norma que se extraiu dele, é inconstitucional.

Para justificar a desnecessidade da comprovação do periculum in mora foi forçoso concluir que referida medida não tem natureza cautelar. Contudo, para não se ter um corpo sem alma, afirmou-se tratar de uma 'tutela de evidência'.

Esqueceu-se, entretanto, de que tutela da evidência pressupõe, sempre, uma defesa da parte adversa, direta ou indireta. Não se defere tutela da evidência sem a oitiva do Réu. O processualista Luiz Guilherme Marinoni esclarece:

21 PEREIRA FILHO, 2016, p. 446.

22 PEREIRA FILHO, 2016, p. 446.

23 Art. $7^{\circ}$ Quando o ato de improbidade causar lesão ao patrimônio público ou ensejar enriquecimento ilícito, caberá a autoridade administrativa responsável pelo inquérito representar ao Ministério Público, para a indisponibilidade dos bens do indiciado. Parágrafo único. A indisponibilidade a que se refere o caput deste artigo recairá sobre bens que assegurem o integral ressarcimento do dano, ou sobre o acréscimo patrimonial resultante do enriquecimento ilícito. 
Ao exigir direito evidente e, assim, não poder dispensar a análise da defesa, tutela da evidência antes da ouvida do réu não é apensas uma contradição em termos; é igualmente uma tutela que viola o contraditório e o direito de defesa. Não há como admitir que um fato constitutivo está provado mediante documento antes da ouvida do demandado. [sem grifo no original $]^{24}$

É imprescindível à tutela da evidência a participação do Réu. Em outras palavras, sua análise está condicionada à defesa apresentada. "A tutela da evidência requer, em regra, fatos constitutivos incontroversos, ou seja, fatos constitutivos provados mediante documento, não contestado ou reconhecidos expressamente na contestação.” 25

A norma que se extraiu no art. $7^{\circ}$ da Lei 8.429/92 contraria a Constituição Federal, como, também, o art. 311, parágrafo único do Código de Processo Civil, ${ }^{26}$ lugar adequado para se falar sobre tutela da evidência.

Em comentário preciso sobre esse artigo, Luiz Guilherme Marinoni aponta sua inconstitucionalidade de forma muito clara:

Em primeiro lugar há absoluta falta de racionalidade no dispositivo. É que obviamente não se pode aferir evidência do direito antes de o réu ter sido citado e apresentado defesa. Note-se, por exemplo, que a alegação de falsidade é suficiente para descaracterizar a evidência das "alegações de fato" e da "prova documental" do contrato de depósito. Isso para não falar que a tutela da evidência sempre depende da análise da consistência da defesa de mérito, direta ou indireta. Os incisos II e III, conforme demonstrado, dizem respeito a situação em que o réu apresenta defesa de mérito indireta infundada que requer instrução dilatória. De modo que é absolutamente impossível aferir os pressupostos para a tutela da evidência liminarmente. [sem grifo no original] ${ }^{27}$

Como visto, a tutela da evidência só se 'evidencia', com perdão pelo solecismo, após a análise da defesa, sendo, pois, impossível deferi-la sem a oitiva do Réu.

A inconstitucionalidade do art. 311, parágrafo único do Código de Processo Civil também é a mesma do art. $7^{\circ}$ da Lei 8.429/92. Ao definir essa medida como sendo 'tutela de evidência', o Superior Tribunal de Justiça, ao frutificar o

24 MARINONI, 2017, pp. 340-341.

25 MARINONI, 2017, p. 340.

26 Art. 311. A tutela da evidência será concedida, independentemente da demonstração de perigo de dano ou de risco ao resultado útil do processo, quando: I - ficar caracterizado o abuso do direito de defesa ou o manifesto propósito protelatório da parte; II - as alegações de fato puderem ser comprovadas apenas documentalmente e houver tese firmada em julgamento de casos repetitivos ou em súmula vinculante; III - se tratar de pedido reipersecutório fundado em prova documental adequada do contrato de depósito, caso em que será decretada a ordem de entrega do objeto custodiado, sob cominação de multa; IV - a petição inicial for instruída com prova documental suficiente dos fatos constitutivos do direito do autor, a que o réu não oponha prova capaz de gerar dúvida razoável. Parágrafo único. Nas hipóteses dos incisos II e III, o juiz poderá decidir liminarmente.

27 MARINONI, 2017, p. 338. 
direito federal, construiu uma norma inconstitucional. Benedito Cerezzo Pereira Filho, em texto publicado na Revista do STJ, alerta:

$\mathrm{O}$ argumento de que a medida cautelar de indisponibilidade de bens prevista no art. $7^{\circ}$ da LIA não é uma medida de urgência, mas tutela de evidência e que por isso prescinde da demonstração do perigo de dano, contraria a natureza, o sentido das tutelas de urgência, que têm como espécies a cautelar e a tutela antecipatória, sendo que esta pode ser prestada, também, se evidente o direito da parte (...) Assim, fumus boni iuris jamais pode ser considerado tutela da evidência. Se o for, o direito terá de ser antecipado, satisfeito. Na LIA, portanto, e em qualquer outra relação de direito processual, tutela da evidência é prestada pela técnica antecipatória e não acautelatória. Agora, a pergunta que não pode deixar de ser feita: na ação de improbidade o juiz, com base no fumus, fumaça, portanto, poderá antecipar o pedido do Ministério Público, satisfazendo sua pretensão? É um pouco mais do que evidente que não. Só se voltarmos naquele passado em que não existiam garantias constitucionais e processuais, cuja interpretação da lei, ao invés de limitar o Poder, concedia-lhe mais força e arbítrio em detrimento do jurisdicionado, sob a especiosa capa do hermetismo de servir ao bem comum. [sem grifo no original] ${ }^{28}$

Ao contrariar a natureza, o sentido das tutelas de urgência, empregando à tutela da evidência um procedimento incompatível com a sua essência, o art. $7^{\circ}$ da Lei 8.429/92, base de toda essa construção jurisprudencial, ganhou o rótulo da inconstitucionalidade.

Assim o é porque o reconhecimento da existência da tutela da evidência em um processo pressupõe, inexoravelmente, a participação do réu. Como visto, é pela análise da sua defesa, direta ou indireta, que se pode averiguar a pertinência do deferimento ou não da tutela da evidência.

Não se pode imaginar, por mais plausível que pareça o direito do autor, que a defesa do réu será inconsistente ao ponto de, primeiro, reconhecer a evidência do direito do autor para, somente depois, ouvi-lo.

Reconhecer um direito como sendo evidente somente pela participação da parte autora, é medida inconciliável com a Constituição Federal já que ofende o intransigível direito fundamental ao contraditório e à ampla defesa.

Não por outra razão, o Supremo Tribunal Federal entendeu ser a matéria passível de repercussão geral, conforme RE n ${ }^{\circ}$ 918.774/BA, Rel. Ministro Marco Aurélio de Melo. Espera-se que, nesse ponto, o Supremo Tribunal Federal coloque as coisas nos seus devidos lugares.

\section{O SISTEMA RECURSAL E O TEMPO DO PROCESSO}

A garantia de princípios fundamentais (segurança jurídica, devido processo legal, contraditório, igualdade etc.) deixou de ser novidade para ser considerada o mínimo que o Estado Democrático e de Direito, detentor do monopó-

28 PEREIRA FILHO, 2016, pp. 446-447. 
lio da justiça, tem para oferecer aos seus jurisdicionados. ${ }^{29}$ Em última análise, é o respeito ao processo civil justo, entendido como a prestação da tutela jurisdicional adequada, tempestiva e efetiva (art. $4^{\circ}, \mathrm{CPC}$ ).

Bem por isso, a máxima, segundo a qual, "O processo deve ser suficiente para restaurar, entre os litigantes, o estado anterior ao conflito de interesses, entregando ao jurisdicionado o mesmo resultado que ele obteria caso houvesse o cumprimento espontâneo dos preceitos legais aplicáveis à situação conflitante" ${ }^{30}$, recebeu da legislação processual cível (CPC/2015) o acréscimo de que essa efetividade tem de ser tempestiva.

Por isso, o Código de Processo Civil pugnou por apresentar uma legislação apta a dar efetividade prática ao princípio constitucional da duração razoável do processo, direito fundamental previsto no art. $5^{\circ}$, LVXXIII da Constituição Federal.

Com esse desiderato, eliminou recursos, como embargos infringentes e agravo retido, ao mesmo tempo em que reservou o Livro V para tratar do procedimento da tutela provisória, abrangendo no Título II a tutela de urgência, compreendida como sendo a cautelar e a antecipatória e, no Título III, a tutela da evidência.

Essa preocupação em sistematizar as tutelas de urgência coaduna com a ideia aqui tratada de que o tempo do processo deve ser enfrentado pelas técnicas antecipatórias, mas, de forma que nenhuma das partes se submeta a uma medida que lhe traga uma insuportabilidade em termos de durabilidade e, igualmente, que não lhes soneguem direito a um contraditório participativo, efetivo.

Firme nesse propósito, no artigo $4^{\circ}$ do $\mathrm{CPC}$, o legislador ordinário afirmou: "As partes têm o direito de obter em prazo razoável a solução integral do mérito, incluída a atividade satisfativa."

Essa 'programação', no entanto, dependia da estrutura do sistema recursal. Não bastava eliminar alguns recursos e nem simplificar o procedimento. Para que o processo tivesse uma duração razoável, pela compreensão que o legislador empregou a esse lapso temporal, seria imprescindível retirar do recurso de apelação o automático efeito suspensivo.

Mudança estrutural que exigiria muito esforço, principalmente de aceitabilidade do novo, para que a jurisdição de primeiro grau fosse vocacionada a tutelar direitos efetivamente, deixando de ser uma mera fase, uma passagem necessária para o real julgamento que somente acontece no segundo grau, ou, até mesmo, após a invocação das Cortes Superiores (STJ e STF).

A Comissão de Juristas responsável pela elaboração do anteprojeto de lei para o Código de Processo Civil não hesitou e, no Senado Federal, apresentou

29 MORAES, 2015, p. 111.

30 MORAES, 2015, p. 98. 
proposta retirando do recurso de apelação seu efeito suspensivo. Tal inovação permitiria, então, a execução (cumprimento) imediato da sentença. Contudo, na Câmara dos Deputados, a situação foi alterada drasticamente.

\subsection{DURAÇÃO RAZOÁVEL DO PROCESSO E DUPLO GRAU OBRIGATÓRIO SÃO PRINCÍPIOS INCONCILIÁVEIS}

O texto "Novo CPC não cria 'ditadura do judiciário"” 31 apontou o equívoco cometido pela Câmara dos Deputados ao reformar o Projeto 166 do Senado Federal que, acertadamente, previa a execução imediata da sentença, distribuindo de forma igualitária o ônus do tempo no processo entre autor e réu. O resultado dessa infeliz alteração foi a aprovação do Código de Processo Civil com a permanência de um duplo grau obrigatório para, só depois, dar-se início a tutela executiva definitiva.

O conto intitulado "A Igreja do Diabo", de Machado de Assis, ${ }^{32}$ com sua sabedoria ímpar, retrata a eterna contradição humana capaz de causar abespinhamento no próprio Diabo. As discussões acerca do Projeto do Novo Código de Processo Civil, votado na Câmara dos Deputados, demonstraram o quanto os processualistas têm sido, no mínimo, contraditórios.

As manifestações, favoráveis e contrárias, à aprovação do referido Projeto foram de argumentos apelativos à previsões futurísticas, cobrança por novidades e por modelo internacional de legislação. ${ }^{33}$

Nesse diálogo 'contraditório' muitos migraram de lado, ora apoiando, ora refutando a aprovação do Projeto, às vezes por convicção, ou, até mesmo, por ter sido convidado a assessorar este ou aquele parlamentar. É evidente que o debate e a opinião, além de fundamentais, são frutos do regime democrático. Não se está aqui, portanto, negando-os, mas apenas procurando entendê-los. ${ }^{34}$

Lógico que, neste espaço, não é possível discorrer sobre os vários argumentos que foram lançados contra a aprovação do Projeto do Novo Código de Processo Civil. Sendo assim, cientes de que, mesmo elegendo um assunto específico, precisar-se-ia de um 'tratado' para contrapor a todos os comentários. A discussão fica limitada, pois, ao ponto que, custou ou custará muito caro à intenção de se projetar um novo e eficaz cenário prático-processual às causas cíveis no Brasil.

Da gramática à prática, parece ser consenso o fato de que o processo civil exala uma morosidade inaceitável. Por isso, seria trivial que o Código de 2015 enfrentasse com agudeza as causas dessa morosidade. Sendo assim, não é preci-

31 PEREIRA FILHO, 2012

32 ASSIS, 2007, pp. 183-190.

33 GAJARDONI, 2013.

34 Acerca da ideia do Diabo, "advertiu o Senhor: Vieste dizê-la, não legitimá-la". ASSIS, 2007, p. 184. 
so muito esforço para se concluir pela necessidade de racionalização do trâmite das ações e, por via oblíqua, pela divisão do tempo do processo entre as partes interessadas na decisão judicial.

Muito embora a reforma processual, ainda sob a égide do Código ab-rogado, levada a efeito em 1994 pela Lei no 8.952 que instituiu a antecipação da tutela, tenha mirado justamente este objetivo - dividir o ônus do tempo entre os litigantes -, a duração do processo ainda ficou a depender, na maioria dos casos, da concordância do réu com a 'justiça' da sentença.

Ao alvedrio do réu, a fase cognitiva será encerrada ou não. Em outras palavras, o bem da vida disputado em juízo só sairá da sua esfera patrimonial caso queira, pois, a simples interposição de um recurso de apelação, ainda que desprovido de fundamentos jurídicos capazes de reformar a decisão de primeira instância, tem vocação inarredável de impedir o trânsito em julgado e, assim, permitir que todo o tempo gasto para o trâmite e julgamento do recurso de apelação seja, também, suportado pelo autor, mesmo sendo ele o vencedor na sentença.

Essa situação foi enfrentada no Projeto $n^{\circ} 166 / 2010$, aprovado no Senado, e a solução encontrada foi a de permitir que a sentença de primeiro grau produzisse efeitos práticos desde já, ou seja, o autor receberia o bem da vida independentemente do recurso de apelação interposto que seria, assim, uma opção do réu, mas, sabedor de que, a não ser em caso de extrema urgência, seu recurso não teria capacidade para impedir que o autor da ação desfrutasse, desde logo, dos efeitos concretos da sentença que lhe foi favorável.

Pensando em termos de duração de um processo, a medida parece lógica. Cada parte suportará o tempo do processo para buscar uma decisão judicial que lhe seja favorável a fim de que possa dela usufruir de forma ampla e eficaz. O autor, salvo nos casos de tutela antecipada, aguardará a prolação da sentença e o réu, o tempo necessário para o tribunal processar e julgar o seu recurso de apelação.

Aliás, não se inventou a roda. Apenas procurou-se albergar no Código de Processo Civil os princípios de justiça previstos na Constituição Federal. No caso, respeitou-se a previsão da duração razoável do processo, artigo $5^{\circ}$, inciso LXXVIII. É mais do que chegada a hora de, realmente, se trabalhar com o decantado processo constitucional.

Essa previsão no Projeto 166/2010 que retirou do recurso de apelação o seu denominado 'efeito suspensivo' foi vista, por alguns processualistas, como uma forma de aumentar o poder do juiz, cunhando a expressão 'ditadura do judiciário’. A discussão, então, ficou na superficialidade do problema. Partiu-se apenas de meras suposições e de uma desconfiança desmedida no juiz de primeiro grau. 
Assim, como "Há muitos modos de afirmar; há só um de negar tudo",35 essas conjecturas bastaram para que, na Câmara dos Deputados, o artigo fosse rejeitado e voltou-se ao que era antes, ou seja: necessidade do duplo grau de jurisdição para o autor ter efetivo acesso ao bem da vida, alvo do litígio.

O juízo de primeiro grau continua sendo apenas uma 'jurisdição de passagem' e a sentença, um mero parecer aguardando a verdadeira decisão que, em última análise, será do réu em permitir ou não a realização do trânsito em julgado.

Em resumo, no novo, prestigiou-se o velho, manteve-se a morosidade em detrimento da efetividade e continuou-se a privilegiar uma parte, no caso o réu, em detrimento do autor que demonstrou, desde a inicial, ter razão.

Eis a eterna contradição humana aqui presente! Mesmo brandindo por efetividade, o processualista preferiu a calmaria do conservadorismo e a manutenção do vetusto procedimento comum e sua desigualdade inerente. ${ }^{36}$

A Câmara dos Deputados viu o novo com o olhar do velho e, assim, acreditando ter inovado, transformou-o em velho. Não se trata, pois, de substituir a vinha do Senhor pela vinha do Diabo, mas, de se perquirir a que melhor atende à sede do povo, com a advertência de Machado de Assis de que a Igreja do Diabo era formalmente perfeita, contudo, humanamente contraditória.

\section{CONSIDERAÇÕES FINAIS}

A alteração, na Câmara dos Deputados, do dispositivo constante do Projeto oriundo do Senado Federal que permitia a sentença produzir seus efeitos no mundo dos fatos enquanto pendente recurso de apelação foi um retrocesso. A justificativa dos processualistas de que tal orientação fortaleceria em demasia o juiz de primeiro grau é, no mínimo, preconceituosa.

Há muito tempo, Luiz Guilherme Marinoni ${ }^{37}$ apregoou a necessidade de se permitir a execução imediata da sentença. É perceptível, pelos seus estudos e, principalmente, pela prática forense, que não faz sentido uma decisão proferida sob o pálio do contraditório e, pois, das garantias constitucionais, ser impedida de produzir efeitos práticos até que o tribunal local se manifeste sobre ela.

O que o Projeto permitia era justamente isso: que a sentença pudesse produzir efeitos no mundo dos fatos ainda que o processo estivesse sob análise do tribunal por força de recurso de apelação. Mas, preocupado com eventuais equívocos e em atenção àqueles casos cuja natureza do direito material controvertido aconselha aguardar o pronunciamento do tribunal, o Projeto remetido à Câmara dos Deputados esmerou-se em permitir ao relator, naquelas situações

35 ASSIS, 2007, p. 183.

36 PEREIRA FILHO; OLIVEIRA, 2005, pp. 295-296.

37 MARINONI, 2000. 
de comprovada necessidade, impedir que essa sentença produzisse seus naturais efeitos, aguardando, então, a decisão do órgão colegiado a seu respeito.

Houve, portanto, a necessária preocupação de se permitir ao jurisdicionado o controle do poder pela atuação colaborativa e efetiva na construção da decisão judicial. A proposta oriunda do Senado Federal em nenhum momento olvidou esse direito fundamental e, inclusive, expressou na denominada 'porta de entrada' do Código quando se referiu, de plano, às Normas Fundamentais do Processo Civil.

Ao contrário da desconfiança apontada pelos reformistas da proposta na Câmara dos Deputados, o Código de Processo Civil esmerou-se na preservação das garantias constitucionais do cidadão, sendo que, por diversas vezes, reforça a necessidade da fundamentação de toda decisão judicial.

Por todo o corpo do texto encontra-se a advertência de que a fundamentação das decisões é necessária. Para ser exato, são 10 (dez) repetições nesse sentido. As redações e alcances dos artigos 11 e 489 ratificam, com proficiência, a preocupação de se permitir um Código de Processo Civil acima de tudo democrático, em estreita consonância com o texto constitucional.

Houve um equilíbrio entre as normas. Ao mesmo tempo em que se atribuiu mais poder ao juiz, se reconheceu que nenhuma decisão judicial pode ser proferida, nem aquelas que podem ser conhecidas de ofício, sem que as partes sejam ouvidas, consoante a garantia constante no art. 10 do diploma processual civil.

Sendo assim, se o objetivo da legislação processual era conceber ao cidadão uma justiça célere, não é possível compreender, pois, o medo da mudança. Aliás, a reforma proporcionada na Câmara dos Deputados, retirando do Código a possibilidade de a sentença produzir efeitos imediatos, é, antes de tudo, contraditória.

Afirma-se isso porque o artigo $4^{\circ}$, seguindo o objetivo inicial do Projeto de Lei 166/2010 de elaborar uma legislação processual que permitisse dar concretude, na prática, aos princípios constitucionais, por isso a preocupação de se iniciar o Código com 'As Normas Fundamentais' (artigos $1^{\circ}$ ao 12), deu ênfase à duração razoável do processo ao prescrever, como já dito: As partes têm o direito de obter em prazo razoável a solução integral do mérito, incluída a atividade satisfativa. Contudo, com alteração perpetrada pela Câmara dos Deputados, esse dispositivo perde eficácia ante a dicção do artigo 1.012: A apelação terá efeito suspensivo.

Como o cidadão obterá a tutela do direito em tempo razoável se para isso terá de se submeter a um obrigatório duplo grau? As duas construções legislativas são contraditórias e, infelizmente, a segunda, torna a primeira letra morta.

Para o jurisdicionado restará demonstrar urgência na solução e efetivação do seu direito, visando convencer o judiciário de que ele merece uma tutela 
preventiva. Ou seja, neste ponto, que parece relevantíssimo, e, talvez, o mais importante para quem realmente pensa em um Código de Processo Civil que prestigie a efetividade, o novo nasceu velho.

\section{REFERÊNCIAS}

ARNAUD, André-Jean. O direito traído pela filosofia. trad. por Wanda de Lemos Capeller e Luciano Oliveira. Porto Alegre: Sergio Antonio Fabris Editor, 1991.

ASSIS, Machado de. O ideal do crítico. In: Obra completa de Machado de Assis. Rio de Janeiro: Nova Aguilar, vol. III, 1994. Publicado originalmente no Diário do Rio de Janeiro, 8/10/1865.

A igreja do diabo. In: 50 contos de Machado de Assis: seleção, introdução e notas John Gledson. São Paulo: Companhia das Letras, 2007. pp. 183-190.

BRASIL. Superior Tribunal de Justiça. Recurso Especial $\mathrm{n}^{\circ} 1.189 .008$ - MT (2010/0065269-8). Rel. Min. Napoleão Nunes Maia Filho. Julgado em 17/05/2016. Publicado no DJE em 17/06/2016.

BRASIL. Superior Tribunal de Justiça. Ação Rescisória n 4590/PR. Rel. Min. Maria Izabel Gallotti. Segunda Seção do Superior Tribunal de Justiça. Processo em andamento.

BRETON, Philippe. A manipulação da palavra. trad. por Maria Stela Gonçalves. São Paulo: Edições Loyola, 1999.

CAPPELLETTI, Mauro. Repudiando Montesquieu? A expansão e a legitimidade da "justiça constitucional". Revista Forense, vol. 366, Rio de Janeiro: Forense, mar.-abr., 2003. pp. 127-150.

CARNELUTTI, Francesco. Diritto e processo. Napoli: Morano, 1958.

DWORKIN, Ronald. O império do direito. trad. por Jefferson Luiz Camargo, São Paulo: Martins Fontes, 2003.

FARIA, José Eduardo (org.). A crise do direito numa sociedade em mudança. Brasília: Editora Universidade de Brasília, 1988.

GAJARDONI, Fernando da Fonseca et alli. A pressa e o projeto do novo CPC. Migalhas $\mathrm{n}^{\circ}$ 3.160. Disponível em: <http:/www.migalhas.com.br/ dePeso/16,MI182166,51045-A+pressa+e+o+projeto+do+novo+CPC> Acesso em: 09 jul. 2013.

JOBIM, Marco Félix. O direito à duração razoável do processo: responsabilidade civil do Estado em decorrência da intempestividade processual. 2. ed., rev. e ampl., Porto Alegre: Livraria do Advogado, 2012.

MARINONI, Luiz Guilherme. Direito fundamental à duração razoável do processo. Estação Científica. Ed. Especial Direito. v. 01, n. 04, Juiz de Fora, outubro e novembro/2009. p. 84. 
. Tutela antecipatória: julgamento antecipado e execução imediata da sentença. 4 ed., atual., e ampl. - São Paulo: Editora Revista dos Tribunais, 2000.

. Tutela de urgência e tutela da evidência: soluções processuais diante do tempo da justiça. 1 ed., São Paulo: Editora Revista dos Tribunais, 2017.

; ARENHART, Sérgio Cruz; MITIDIERO, Daniel. Novo código de processo civil comentado. 2 ed., rev., atual. e ampl. São Paulo: Editora Revista dos Tribunais, 2016.

; ARENHART, Sérgio Cruz; MITIDIERO, Daniel. Novo curso de processo civil: teoria geral do processo civil. vol. 1, 2 ed., rev., atual. e ampl. São Paulo: Editora Revista dos Tribunais, 2016.

MORAES, Daniela Marques de. A importância do olhar do outro para a democratização do acesso à justiça. Rio de Janeiro: Lumen Juris, 2015.

OST, François. O tempo do direito. trad. por Élcio Fernandes. Bauru/SP: EDUSC, 2005.

PEREIRA FILHO, Benedito Cerezzo. A atuação do juiz no novo código de processo civil. Revista Consultor Jurídico. 30 mar. 2015. Disponível em: http:// www.conjur.com.br/2015-mar-30/benedito-cerezzo-atuacao-juiz-codigoprocesso-civil

- A duração razoável do processo na perspectiva do novo código de processo civil - lei $\mathrm{n}^{\circ} 13.105$, de 16 de março de 2015. In: O novo código de processo civil: questões controvertidas. Vários autores. São Paulo: Atlas, 2015.

. As improbidades da lei de improbidade. Revista do Superior Tribunal de Justiça - Improbidade administrativa. ano 28, n. 241, jan/fev/mar 2016. p. 446.

. Novo CPC não cria ‘ditadura do judiciário'. Revista Consultor Jurídico. 12 de janeiro de 2012. Disponível em: http://www.conjur.com.br/2012-jan-12/ nao-dizer-cpc-cria-ditadura-judiciario

. O poder do juiz: ontem e hoje. Revista da AJURIS. v. 104, Porto Alegre: AJURIS, 2006. pp. 19-33.

PEREIRA FILHO, Benedito Cerezzo; OLIVEIRA, Emerson Ademir Borges de. A estrutura do código de processo civil: uma afronta à igualdade! In: CONGRESSO NACIONAL DO CONPEDI, 14., 2005, Florianópolis. Anais. Florianópolis: Fundação Boiteux, 2005.

Recebido em: 04/02/2019. Aprovado em: 30/05/2019. 